\title{
Potential of germanium-based compounds in coronavirus infection
}

VIOLETTA NAROKHA* IRYNA NIZHENKOVSKA OLENA KUZNETSOVA

Department of Pharmaceutical Biological and Toxicological Chemistry Faculty of Pharmacy, Bogomolets National Medical University Kyiv, Ukraine
Accepted May 18, 2021

Published online May 22, 2021

The first germanium compounds which exhibited immunomodulatory and antiviral effects were sesquioxane-type germanates. To date, more than a dozen compounds containing germanium have been synthesized and are being actively studied. They include germanium carboxylates and citrates, complexes of germanium with resveratrol, daphnetin, mangiferin, chrysin, quercetin, ascorbic and nicotinic acids, amino acids, gamma-lactones, germanium-containing spirulina, yeast and others. Germanium-based compounds have shown the ability to influence the replication of various DNA/RNA viruses, stimulate the body's natural resistance, prevent the development of metabolic intoxication of various origin, increase the efficacy of vaccines, and prevent the development of excessive accumulation of reactive oxygen species, which plays a decisive role in the development of inflammatory response caused by a viral infection. It seems reasonable to say that germanium-based complex compounds effectively contribute to the preservation of high-energy bonds in the form of ATP, optimize the activity of metabolic processes by re-oxygenation, and exhibit antimicrobial activity. The purpose of this review is to summarize the pharmacological potential of various germanium-based compounds studied nowadays, taking into account their mechanisms of action, and to analyze their prospects in the development of integrated approaches in the prevention and treatment of SARS-CoV-2 infection.

Keywords: germanium, organic germanium, SARS-CoV-2, COVID-19

\section{INTRODUCTION}

The study of the causative agent of the severe acute respiratory syndrome (SARS), the outbreak of which has swept the world since 2019, allowed for the identification of a new virus, which was defined by the International Committee on Virus Taxonomy as SARScoronavirus-2 (SARS-CoV-2) (1), and the disease caused by SARS-CoV-2. It can affect patients of all ages and manifest itself as an asymptomatic carrier state, acute respiratory

\footnotetext{
*Correspondence; e-mail address: v.narokha@ukr.net
} 
infections or pneumonia and has been officially recognized by the WHO as COronaVIrus Disease (COVID-19) (2).

The literature describes various mechanisms of pathogenesis of COVID-19, from interaction with the angiotensin-converting enzyme 2 receptor and trans-membrane serine proteases 2, cathepsin L and furin, or possible involvement of the myeloid compartment (3) to dysregulation of adaptive immunity (4), including a cytokine storm (5), which in severe cases causes an acute respiratory distress syndrome (6). Several recent reports mention the occurrence of lymphopenia (7), increased activity of cluster of differentiation (CD) 8 T-cells compared to CD4 T-cells (8), and functional depletion of cytotoxic lymphocytes (9).

People infected with the SARS-CoV-2 virus experience a phenomenon described as "quiet" or "happy" hypoxia, characterized by the absence of visible functional disorders with low blood oxygen saturation (10). According to some reports, saturation parameters can decrease to the range of $50-80 \%$ without causing complaints, whereas in healthy people the saturation is at least $95 \%$. A mysterious finding can be dangerous as the patient does not feel much discomfort, but the level of oxygen in his/her lungs is so low that it can cause a rapid loss of consciousness or even death $(11,12)$.

Some authors believe that the onset of severe damage to organs, primarily the lungs, depends on the activation of the oxidative stress mechanism, which is associated with innate immunity (13). Overproduction of reactive oxygen species (ROS) and deprivation of antioxidant mechanisms result in oxidative damage to healthy cells (14) and enhance the host's inflammatory response to the virus (15), which are critical for viral replication and the development of subsequent disease symptoms (16). Complications observed in patients with COVID-19, such as hypoxemia, bilateral pneumonia or acute respiratory distress syndrome can result in pulmonary edema and pulmonary failure, arrhythmias, shock, acute heart damage, liver dysfunction, renal failure, secondary infections (7), neurological and neurodegenerative disorders (17), coagulation dysfunction (18) and affect lifestyle (19).

Like other viruses, SARS-CoV-2 has many potential natural intermediate and final hosts, which pose serious problems for the prevention and treatment of viral infection (20, 21). While our understanding of COVID-19 pathogenesis is advancing rapidly through global research efforts of unprecedented proportions, there is still scientific debate on both the accuracy of diagnosis and prevention and treatment of the disease in different populations.

The purpose of this study was to review the literature and analyze the mechanisms of possible therapeutic activity of germanium-containing compounds in order to further optimize prevention and develop comprehensive methods to combat COVID-19.

Systematic content analysis using the main online databases (PubMed, Google Scholar, MEDLINE, UpToDate, Embase and Web of Science) was used.

\section{GERMANIUM-CONTAINING COMPOUNDS WITH POTENTIAL THERAPEUTIC VALUE}

\section{Sesquioxane-type germanium compounds}

The most studied and well-known germanium-containing compound is Ge-132 or carboxyethylgermanium sesquioxide, or poly-trans-[(2-carboxyethyl) germasesquioxane, $\left[\left(\mathrm{GeCH}_{2} \mathrm{CH}_{2} \mathrm{COOH}\right)_{2} \mathrm{O}_{3}\right]$ (also known as repagermanium, propagermanium or proxiger- 
manium) (Fig. 1a) (22). It showed antioxidant properties in vitro in the liver tissues by reducing the activity of NADPH oxidases and xanthine oxidase and increased activity of superoxide dismutase and catalase (23), changed oxidative properties of bilirubin in the bile (24), influenced sensitivity of plasma low-density lipoproteins to oxidation and the morphology of atherosclerosis in the aorta and coronary artery (25), reduced intensity of DNA strand breaking, malondialdehyde levels and increased activity of superoxide dismutase and catalase in the liver (26).

The results of Ge-132 effects on the processes of oocyte maturation demonstrated changes in mRNA expression associated with the nuclear factor erythroid 2-related factor 2 gene and the pro-apoptotic Bax gene; a decrease in the levels of intracellular reactive oxygen species and apoptosis intensity caused by oxidative stress in the oocytes during their maturation (27). The results of other recent studies suggested the mechanism of Ge-132 immunomodulatory and antioxidant effects via changes in the expression of more than 1200 genes associated with transport proteins, antioxidant activity, lipid metabolism, ATP synthesis and apoptosis (28). Data on increased mRNA expression, fibroblast proliferation and collagen fiber formation associated with a decrease in edema (29) can be taken into account in the development of comprehensive approaches to the restoration of damaged epithelium. In addition, it was suggested that Ge-132, comprising three oxygen atoms, is an effective electron donor. It amalgamates with free radicals and eliminates them from the body through excretion (30).

Activation of CD4, CD8 T-cells and natural killer (NK) cells, as well as induction of the production of several cytokines induced by Ge-132, suggest this compound as a nonspecific immunomodulator for the treatment of patients with chronic hepatitis B (31).

In water, Ge-132 is hydrolyzed to 3-(trihydroxygermyl)propanoic acid (Fig. 1b), which can interact with cis-diol-containing compounds of the nucleic acids (32), inhibit the expression of the genes associated with cell death and inflammatory response and exhibit antioxidant properties, which, according to the authors, are not associated with direct absorption of ROS (33).

In early studies in mice infected with an adapted strain of influenza A subtype H2N2, the antiviral activity of Ge-132 was demonstrated through an increase in the number of surviving animals and survival days, as well as a decrease in the titer of the virus in the lung tissues. Since no in vitro virucidal or virostatic activity of Ge-132 was detected, these protective effects in mice against influenza virus could be manifested through the immunomodulatory activity of this compound, i.e., an increase in the activity of NK cells (34). Similar immunological effects, including an increase in the activity of NK cells, were observed in the later studies in dogs with adenocarcinoma (35).

In addition to the aforementioned recent data $(23,33)$, the antiviral activity of Ge-132 was observed in cytomegalovirus infection model back in the 1980-90s (36), immunomodulatory activity, including the mechanisms involving macrophages and/or T-cells, in the experimental tumor models of ascites in mice $(37,38)$ and the transformation of T-lymphocytes in chicken infected with Marek's virus (39), as well as the ability to influence interferon synthesis (40-43). Ge-132 may be useful as an inducer of counter-suppressive T-cells in immunocompromised individuals, who have suppressive T-cell. Elimination of suppressor T-cells in immunocompromised hosts can result in an increased resistance to various opportunistic infections (44). There is evidence that Ge-132 was able to reduce the manifestations of oxidative stress during the use of steroid anti-inflammatory drugs (45), 
to restore the properties of leukocytes and stabilize their membranes (46), to improve cell metabolism (47) and to enhance the production of interferon (IFN)- $\alpha / \beta$ in mice infected with influenza virus (48). Although Ge-132 did not suppress in vitro multiplication of various DNA or RNA viruses, its oral administration increased the survival rate in animals and decreased the manifestations of symptoms of Herpes simplex virus type I (HSV-1) infection through the induction of cytotoxic T-lymphocytes against antigen HSV-1, reduced the intensity of symptoms of vaccinia virus infection by the number of pocks on the tail and enhanced IFN- $\gamma$ induction in mice treated with Mycobacterium bovis (49).

Some authors consider neglect of the potential clinical use of this unique germanium compound to be very hasty (50), and despite contradictory data on its effects in the body (51), there are some very convincing results regarding the low toxicity of germanium-organic polymers of the germsesquioxane type (52).

\section{Other germanium-based compounds}

Bis(pyridine-2,6-dicarboxylate)germanium. - Bis(pyridine-2,6-dicarboxylate) germanium (Fig. 1c) is a component of the drug Maxidin 0.4, which is prescribed for the treatment and prevention of viral infections in small animals (53). The drug has immunomodulatory and antiviral effects, stimulates the body's natural resistance, increases the activity of the effector cells of the immune system, exhibits a pronounced interferonogenic activity, stimulating the synthesis of both early (mainly IFN- $\alpha / \beta$ ) and late (mainly IFN- $\gamma$ ) interferon, blocking the translation of viral proteins, significantly enhances the functional activity of macrophages - phagocytosis, chemotaxis, oxidative metabolism and lysosomal activity $(53,54)$. In addition, bis(pyridine-2,6-dicarboxylate) germanium had a prophylactic value in metabolic intoxication during the period of various immunodeficiencies (55).

Germanium nanocarboxylate. - Germanium nanocarboxylate is a component of Hermakap, a trace element supplement, which, when administered for 5 days before and after vaccinations against viral diseases in birds, resulted in an increase in specific antibodies against infectious bursal disease, infectious bronchitis in chicken and group immunity to Newcastle disease (57). When this drug was used in calves, the activation of hematopoiesis and restoration of the structure of this system was observed in terms of leukocyte, segmented neutrophil and eosinophil levels, lymphocyte content, in a significant increase in total protein and its gamma-globulin fraction, as well as in phagocytic activity of the neutrophils (58).

Aluminosilicate mineral germanium. - The studies of Germanium Biotite, a supplement containing the aluminosilicate mineral germanium, showed an increase in the immune response to the aphthous fever vaccine (59), an increase in the proliferative response of lymphocytes and lysozyme activity (60) and preventive effects against respiratory disease in cattle (61).

Given the ability of SARS-CoV-19 to be transmitted from animals to humans, the prevention of the latter's morbidity can play an important role in the prevention of pandemics.

Nanogermanium citrate. - Its use in the experiment had a protective effect on thymus and lymph node cells, reducing their DNA damage and death, which may be mediated by the observed certain normalization of neutrophil functions (62). An improvement in the parameters of the immune and antioxidant systems was confirmed by the bottom content 
a)<smiles>O=C(O)CC[Ge](=O)O[Ge](=O)CCC(=O)O</smiles>

c)<smiles>O=C1O[Ge]2(OC(=O)c3cccc1n3)OC(=O)c1cccc(n1)C(=O)O2</smiles>

e)

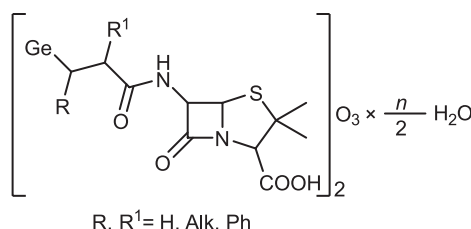

b)<smiles>[O][Ge](O)(O)CCCC(=O)O</smiles>

d)

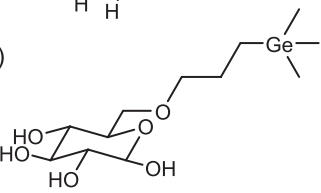

f)<smiles>[R]C=[N+]=O</smiles>

Fig. 1. Germanium-based compounds: a) Ge-132 or carboxyethylgermanium sesquioxide, propagermanium (22), b) 3-(trihydroxygermyl)propanoic acid (98), c) bis(pyridine-2,6-dicarboxylate) germanium (56), d) 6-O-[3-(trimethylgermyl)propyl]- $\beta$-D-glucopyranoside (72), e) $\beta$-lactam derivatives of germanium (48), f) trimethylgermanyl-furan (48).

of immune globulins, glycoproteins and the activity of antioxidant defence enzymes in pregnant rats (63), as well as immunological parameters and a decrease in the intensity of lipid peroxidation in infant rats (64).

1-Hydroxygermatranil citrate. - The findings of Liashenko et al. $(65,66)$ indicating the ability of 1-hydroxygermatranil citrate to enhance the effects of the Vaxigrip vaccine, may be of interest for the prevention of viral pandemics after COVID-19 and can be proposed as an adjuvant treatment after further studies.

Bio-germanium systems. - An increase in the activity of germanium-containing spirulina, compared to dietary spirulina, was observed in terms of plasma levels of IFN- $\gamma$ and tumour necrosis factor (TNF)- $\alpha$, an increase in the activity of catalase and glutathione peroxidase, as well as the level of oxidized glutathione in the liver under conditions of an experimental model of hepatitis (67).

Bio-germanium synthesized using a yeast culture process has shown immunostimulatory effects by increasing the cytotoxicity of NK cells and activating immunoglobulins, $B$ cells and TNF- $\alpha$ in volunteers (68). Given the data on the low toxicity of germanium-enriched yeast (69), its ability to induce macrophage activation, thereby increasing their function (70), as well as its anti-inflammatory activity, partially associated with inhibition of arachidonic acid release and prostaglandin $\mathrm{E}_{2}$ production in cancer basophilic cells (71), this supplement can also be considered in the process of complex modulation of immunological homeostasis during coronavirus infection.

6-O-[3-(trimethylgermyl)propyl]-beta-D-glucopyranoside. - 6-O-[3-(trimethylgermyl) propyl]- $\beta$-D-glucopyranoside (Fig. 1d) was a better inducer of IFN- $\gamma$ than Ge-132, in animal studies (72). 
Organogermanium poly-derivatives. - The anti-respiratory virus activity of organogermanium poly-derivatives, compared to ribavirin, has been confirmed in vitro (73).

There is evidence that $\beta$-lactam derivatives of germanium (Fig. 1e), in addition to inhibition of pathogenic microorganism growth, including Staphylococcus aureus and Staphylococcus epidermidis, are able to exert a synergistic effect on $\beta$-lactam antibiotics (48).

Trimethylgermatril-furans (Fig. 1f) show high bacteriostatic activity against Staphylococcus aureus and Escherichia coli (48), which can be taken into account to prevent the development of complications of bacterial etiology.

Complexes of germanium with flavonoids, polyphenols, vitamins, amino acids and gammalactones. - The study of germanium-containing complexes with biologically active compounds is due to their ability to synergize the pharmacological activity of individual components of the complex, which was confirmed by the antioxidant activity of the Ge-resveratrol complex (Fig. 2a), the mechanism of action of which is associated with the presence of the-Ge-O- bond (74), complexes of germanium with polyphenols, namely, Gedaphnitine (Fig. 2b) and Ge-mangiferin (Fig. 2c) (75), and chrysin-Ge (Fig. 2d) (76).

Taking into account the data on the interactions between SARS-CoV-2 and erythrocytes and their effect on the hemes and porphyrin, the quercetin-Ge ${ }_{2}$ complex (Fig. 2e) is of interest, which is able to reduce oxidative damage to human erythrocytes and restore the morphology of the cell surface, the potential of the plasma membrane and intracellular levels of free $\mathrm{Ca}^{2+}(77)$.

The combination of organogermanium with ascorbic acid (Fig. 2f), in addition to significant antioxidant properties $(78,79)$, has demonstrated the ability to restore the barrier function of the skin, to reduce trans-membrane water loss and immunoglobulin E production in a model of chronic contact dermatitis (80), which can be useful in the development of complex approaches to restoration of epithelial tissue of the lungs in patients who suffered from COVID-19.

Antimicrobial activity and highly selective antibacterial action of germa-gammalactones (Fig. 2g) against Gram-negative bacteria (81) may be important for the prevention of opportunistic infections.

The immunomodulatory effects of germanium combinations with amino acids (bishistidino germinate (Fig 2h), bis-methionino germanate (Fig. 2i) and bis-glutathiono germanate) (Fig. 2j) were studied in terms of in vivo interleukin-12 and IFN- $\gamma$ levels, and the mechanism of these changes was determined as neurochemical (82). Among the compounds studied, bis-methionino germanate was found to be the best interferon inducer that improved immunological function.

Coordination compounds of germanium with organic bio-ligands. - The therapeutic potential of the coordination compounds of germanium with nicotinic acid (Fig. 2k) is expressed as the prevention of excessive accumulation of ROS, possibly through its superoxide dismutase activity $(83)$, lipid $(84,85)$ and proteins peroxidation products $(86)$, which play a key role in the development of inflammatory reactions caused by a viral infection.

Since oxidative stress plays an important role in the initiation and persistence of lung injury and inflammation, approaches combining ROS removal with inhibition of viral replication may be effective in modulating severe lung disease associated both with SARS-CoV-2 and other respiratory viral infections. In addition, given the pharmacological activity of 
a)<smiles>CC(Cc1ccc(O)cc1)c1cc(O)cc(O)c1</smiles>

c)<smiles>CCO[P@]1(O)Oc2cc3oc4cc(O)c(C5C[C@H](O)[C@@H](O)[C@H](O)[C@H]5O)c(O)c4c(=O)c3cc2O1</smiles>

e)

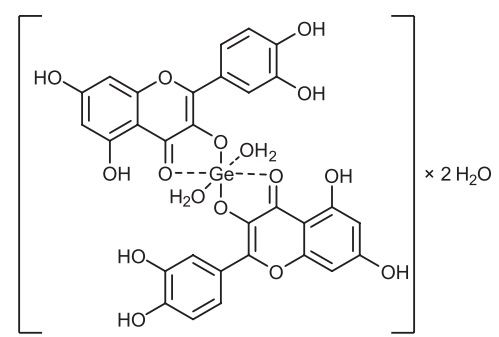

f)<smiles>C[Ge](C)(C)CCC(=O)NC[C@H](O)C1OC(=O)C(O)=C1O</smiles>

h)<smiles>NC(Cc1c[nH]cn1)C(=O)O</smiles>

j)<smiles>NC(CCC(=O)NC(CS)C(=O)NCC(=O)O)C(=O)O</smiles>

g)

i)

k) b)<smiles>CO[Ge]1(OC)Oc2ccc3ccc(=O)oc3c2O1</smiles>

d)<smiles>O=c1cc(-c2ccccc2)oc2cc(O[Ge](c3ccccc3)(c3ccccc3)c3ccccc3)cc(O)c12</smiles><smiles>OC1=C2O[Ge]OC2=C(c2ccc3c(c2)OCO3)Oc2cc(O)cc(O)c21</smiles>

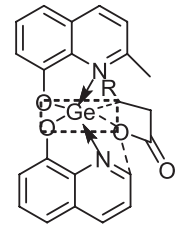<smiles>CC(C)SCCC(N)C(=O)O</smiles>

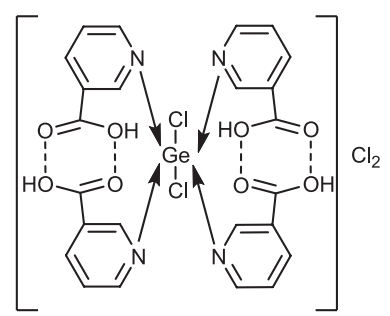

Fig. 2. Structures of germanium complexes with flavonoids, polyphenols, vitamins, amino acids and gamma-lactones: a) Ge-resveratrol (74), b) Ge-daphnitine (75), c) Ge-mangiferin (75), d) Ge-chrysin (76), e) Ge-quercetin (99) and $\mathrm{Ge}_{2}$-quercetin (77), f) organogermanium with ascorbic acid $(79,80)$, g) germagamma-lactones (81), h) bis-histidino germanate (82), i) bis-methionino germanate (82), j) bis-glutathiono germanate (82), k) germanium complex with nicotinic acid (94). 
nicotinic acid (87-89), further studies of germanium complex with nicotinic acid (86) seem promising. There are also reasons to assume that coordination compounds of germanium with nicotinic acid and nicotinamide, due to their membrane-protective activity, effectively contribute to the preservation of the levels of adenyl nucleotides, which are disrupted under conditions of exo- (90) and endo-toxemia $(91,92)$. In experimental re-oxygenation following hypoxia associated with hypercapnia, the coordination compounds of germanium showed the ability to stabilize the processes of oxygen uptake by the tissues by activating the main buffer systems of blood plasma, and also to optimize the level of metabolic processes by reducing the rate of $\mathrm{O}_{2}$ extraction from the blood by the cells $(93,94)$. The data on the dose dependence of the antihypoxic effects of tartaric acid-based coordination compound of germanium with manganese (95) can also be taken into account in further studies of this group of compounds, and the in vitro anti-staphylococcal activity of the germanium complex with citric acid (96), and the effect of a number of germanium complexes with succinic, hydroxyethyliminodiacetic and iminodisuccinic acids on the synthesis and activity of collagenase enzymes, $\alpha$-N-acetylgalactosaminidase and $\alpha$-galactosidase (97) can play an important role in the prevention of opportunistic infections.

\section{CONCLUSIONS}

In this review, germanium-containing compounds of various structures and their main biochemical mechanisms of action are discussed. Hypotheses of their potential therapeutic activity in the development of complex approaches in the prevention and treatment of SARS-CoV-2 infection are proposed, including the effects on the reproduction of various DNA/RNA viruses, stimulation of the body's natural resistance, prevention of the development of metabolic intoxication of various etiologies, increased efficacy of vaccines, prevention of excessive accumulation of reactive oxygen species, preservation of highenergy bonds, as well as optimization of the activity of metabolic processes through re-oxygenation and antimicrobial activity. At the same time, despite the promising use of germanium-containing compounds for the development of approaches in the prevention and treatment of coronavirus infection, further comprehensive studies of the pharmacological mechanism of action of each of them are still required.

Abbreviations, acronyms, symbols. - ATP - adenosine triphosphate, CD cells - cluster of differentiation cells, IFN - interferon, NADPH - nicotinamide adenine dinucleotide phosphate, NK - natural killer, ROS - reactive oxygen species, SARS - severe acute respiratory syndrome, SARS-CoV-2 - severe acute respiratory syndrome coronavirus-2, TNF - tumour necrosis factor

\section{REFERENCES}

1. National Library of Medicine, U. S. Department of Health and Human Services, Severe Acute Respiratory Syndrome Coronavirus 2, NCBI:txid2697049; https://www.ncbi.nlm.nih.gov/Taxonomy/Browser/ wwwtax.cgi?id=2697049; last access date March 10, 2021

2. World Health Organisation, Coronavirus Disease 2019 (COVID-19) Situation Report-40, WHO Geneva, February 2020; https://www.who.int/docs/default-source/coronaviruse/situation-reports/20200229sitrep-40-covid-19.pdf; last access date March 10, 2021

3. J. Schulte-Schrepping, N. Reusch, D. Paclik, K. Baßler, S. Schlickeiser, B. Zhang, B. Krämer, T. Krammer, S. Brumhard, L. Bonaguro, E. De Domenico, D. Wendisch, M. Grasshoff, T. S. Kapellos, M. 
Beckstette, T. Pecht, A. Saglam, O. Dietrich, H. E.Mei, A. R. Schulz, C. Conrad, D. Kunkel, E. Vafadarnejad, C.-J. Xu, A. Horne, M. Herbert, A. Drews, C. Thibeault, M. Pfeiffer, S. Hippenstiel, A. Hocke, H. Müller-Redetzky, K.-M. Heim, F. Machleidt, A. Uhrig, L. B. de Jarcy, L. Jürgens, M. Stegemann, C. R. Glösenkamp, H.-D. Volk, C. Goffinet, M. Landthaler, E. Wyler, P. Georg, M. Schneider, C. Dang-Heine, N. Neuwinger, K. Kappert, R. Tauber, V. Corman, J. Raabe, K. M. Kaiser, M. T. Vinh, G. Rieke, C. Meisel, T. Ulah, M. Becker, R. Geffers, M. Witzenrath, C. Drosten, N. Suttop, C. von Kalle, F. Kurth, K. Händler, J. L. Schultze, A. C. Aschenbrenner, Y. Li, J. Nattermann, B. Sawitzki, A.-E. Saliba and L. E. Sander, Severe COVID-19 is marked by a dysregulated myeloid cell compartment, Cell 182 (2020) 1419-1440; https://doi.org/10.1016/j.cell.2020.08.001

4. X. Yang, T. Dai, X. Zhou, H. Qian, R. Guo, L. Lei, X. Zhang, D. Zhang, L. Shi, Y. Cheng, J. Hu, Y. Guo and B. Zhang, Analysis of adaptive immune cell populations and phenotypes in the patients infected bySARSCoV-2, medRxiv preprint; postedDecember21,2020;https://doi.org/10.1101/2020.03.23.20040675

5. C. Huang, Y. Wang, X. Li, L. Ren, J. Zhao, Y. Hu, L. Zhang, G. Fan, J. Xu, X. Gu, Z. Cheng, T. Yu, J. Xia, Y. Wei, W. Wu, X. Xie, W. Yin, H. Li, M. Liu, Y. Xiao, H. Gao, L. Guo, J. Xie, G. Wang, R. Jiang, Z. Gao, Q. Jin, J. Wang and B. Cao, Clinical features of patients infected with 2019 novel coronavirus in Wuhan, China, Lancet 395 (2020) 497-506; https://doi.org/10.1016/S0140-6736(20)30183-5

6. Z. Xu, L. Shi, Y. Wang, J. Zhang, L. Huang, C. Zhang, S. Liu, P. Zhao, H. Liu, L. Zhu, Y. Tai, C. Bai, T. Gao, J. Song, P. Xia, J. Dong, J. Zhao and F.-S. Wang, Pathological findings of COVID-19 associated with acute respiratory distress syndrome, Lancet Respir Med. 8 (2020) 420-422; https://doi.org/10.1016/ S2213-2600(20)30076-X

7. G. Pascarela, A. Strumia, C. Piliego, F. Bruno, R. Del Buono, F. Costa, S. Scarlata and F. E. Agro, COVID-19 diagnosis and management: a comprehensive review, J. Intern. Med. 288 (2020) 192-206; https://doi.org/10.1111/joim.13091

8. I. Thevarajan, T. H. O. Nguyen, M. Koutsakos, J. Druce, L. Caly, C. E. van de Sandt, X. Jia, S. Nicholson, M. Catton, B. Cowie, S. Y. C. Tong, S. R. Lewin and K. Kedzierska, Breadth of concomitant immune responses prior to patient recovery: a case report of non-severe COVID-19, Nat. Med. 26 (2020) 453-455; https://doi.org/10.1038/s41591-020-0819-2

9. M. Zheng, Y. Gao, G., Wang, G. Song, S. Liu, D. Sun, Y. Xu and Z. Tian, Functional exhaustion of antiviral lymphocytes in COVID-19 patients, Cell. Mol. Immunol. 17 (2020) 533-535; https://doi. org/10.1038/s41423-020-0402-2

10. S. Dhont, E. Derom, E. Van Braeckel, P. Depuydt and B. N. Lambrecht, The pathophysiology of 'happy' hypoxemia in COVID-19, Respir. Res. 21 (2020) Article ID 198; https://doi.org/10.1186/s12931020-01462-5

11. W. Ottestad and S. Søvik, COVID-19 patients with respiratory failure: what can we learn from aviation medicine? Br. J. Anaesth. 125 (2020) 280-281; https://doi.org/10.1016/j.bja.2020.04.012

12. M. R. Geier and D. A. Geier, Respiratory conditions in coronavirus disease 2019 (COVID-19): Important considerations regarding novel treatment strategies to reduce mortality, Med. Hypotheses 140 (2020) Article ID 109760; https://doi.org/10.1016/j.mehy.2020.109760

13. L. Delgado-Roche and F. Mesta, Oxidative stress as key player in severe acute respiratory syndrome coronavirus (SARS-CoV) infection, Arch. Med. Res. 51 (2020) 384-387; https://doi.org/10.1016/j. arcmed.2020.04.019

14. N. Komaravelli and A. Casola, Respiratory viral infections and subversion of cellular antioxidant defenses, J. Pharmacogenomics Pharmacoproteomics 5 (2014) Article ID 1000141; https://doi. org/10.4172/2153-0645.1000141

15. Y. Fu, Y. Cheng and Y. Wu, Understanding SARS-CoV-2-mediated inflammatory responses: from mechanisms to potential therapeutic tools, Virol. Sin. 35 (2020) 266-271; https://doi.org/10.1007/s12250020-00207-4

16. O. A. Khomich, S. N. Kochetkov, B. Bartosch and A. V. Ivanov, Redox biology of respiratory viral infections, Viruses 10 (2018) Article ID 392; https://doi.org/10.3390/v10080392 
17. F. G. De Felice, F. Tovar-Moll, J. Moll, D. P. Munoz and S. T. Ferreira, Severe acute respiratory syndrome coronavirus 2 (SARS-CoV-2) and the central nervous system, Sci. Soc. 43 (2020) 355-357; https://doi.org/10.1016/j.tins.2020.04.004

18. D. Giannis, I. A. Ziogas and P. Gianni, Coagulation disorders in coronavirus infected patients: COVID-19, SARS-CoV-1, MERS-CoV and lessons from the past, J. Clin. Virol. 127 (2020) Article ID 104362; https://doi.org/10.1016/j.jcv.2020.104362

19. M. Mititelu, T. I. Stanciu, D. I. Udeanu, D. E. Popa, D. Drăgănescu, C. Cobelschi, N. D. Grigore, A. L. Pop and M. Ghica, The impact of COVID-19 lockdown on the lifestyle and dietary patterns among Romanian population, Farmacia 69 (2021) 1-11; https://doi.org/10.31925/farmacia.2021.1.1

20. O. G. Olaru, D. C. Badiu, A. D. Stanescu, C. M. Pena, R. I. Papacocea and A. B. Stroescu, Study of available antiviral treatment for COVID-19 during pregnancy, Farmacia 68 (2020) 957-965; https://doi. org/10.31925/farmacia.2020.6.1

21. A. L. Arsene, I. B. Dumitrescu, C. M. Dragoi, D. I. Udeanu, D. Lupuliasa, V. Jinga, D. Drăgănescu, C. E. Dinu-Pirvu, G. Trian, A. B. Dragomiroiu, I. E. Blejan, R. E. Moisu, A. Crenguta Nicolae, H. Moldovan, D. E. Popa, B. S. Velescu and S. Ruta, A new era for the therapeutic management of the ongoing COVID-19 pandemic, Farmacia 68 (2020) 185-196; https://doi.org/10.31925/farmacia.2020.2.1

22. National Library of Medicine, National Center for Biotechnology Information, Propagermanium (Compound); https://pubchem.ncbi.nlm.nih.gov/compound/Propagermanium; last access date May 16,2021

23. T. Tezuka, A. Higashino, M. Akiba and T. Nakamura, Organogermanium (Ge-132) suppresses activities of stress enzymes responsible for active oxygen species in monkey liver preparation, Adv. Enzyme Res. 5 (2017) 13-23; https://doi.org/10.4236/aer.2017.52002

24. T. Nakamura, T. Nagura, M. Akiba, K. Sato, Y. Tokuji, M. Ohnishi and K. Osada, Promotive effects of the dietary organic germanium poly-trans-[(2-carboxyethyl) germasesquioxane] (Ge-132) on the secretion and antioxidative activity of bile in rodents, J. Health Sci. 56 (2010) 72-80; https://doi.org/10.1248/ jhs.56.72

25. Y. Wakabayashi, Effect of germanium-132 on low-density lipoprotein oxidation and atherosclerosis in Kurosawa and Kusanagi hypercholesterolemic rabbits, Biosci. Biotechnol. Biochem. 65 (2001) 18931896; https://doi.org/10.1271/bbb.65.1893

26. M. K. Yang and Y. G. Kim, Protective role of germanium-132 against paraquat-induced oxidative stress in the livers of senescence-accelerated mice, J. Toxicol. Environ. Health A 58 (1999) 289-297; https://doi.org/10.1080/009841099157250

27. E. Kim, Y. Jeon, D. Y. Kim, E. Lee and S-H. Hyun, Antioxidative effect of carboxyethylgermanium sesquioxide (Ge-132) on IVM of porcine oocytes and subsequent embryonic development after parthenogenetic activation and IVF, Theriogenology 84 (2015) 226-236; https://doi.org/10.1016/j. theriogenology.2015.03.006

28. T. Nakamura, T. Takeda and Y. Tokuji, The oral intake of organic germanium, Ge-132, elevates $\alpha$-tocopherol levels in the plasma and modulates hepatic gene expression profiles to promote immune activation in mice, Int. J. Vitam. Nutr. Res. 84 (2014) 183-195; https://doi.org/10.1024/0300-9831/ a000205

29. H. Matsumoto, H. Iwafuji, J. Yamane, R. Takeuchi, T. Utsunomiya and A. Fujii, Restorative effect of organic germanium compound (Ge-132) on dermal injury, Wound Med. 15 (2016) 6-10; https://doi. org/10.1016/j.wndm.2016.09.001

30. B. S. Sekhon, Metalloid compounds as drugs, Res. Pharm. Sci. 8 (2013) 145-158.

31. C. Hirayama, H. Suzuki, M. Ito, M. Okumura and T. Oda, Propagermanium: a nonspecific immune modulator for chronic hepatitis B, J. Gastroenterol. 38 (2003) 525-532; https://doi.org/10.1007/s00535003-1098-7

32. Y. Shimada, K. Sato, T. Takeda and Y. Tokuji, The organogermanium compound Ge-132 interacts with nucleic acid components and inhibits the catalysis of adenosine substrate by adenosine deaminase, Biol. Trace Elem. Res. 181 (2018) 164-172; https://doi.org/10.1007/s12011-017-1020-4 
33. T. Takeda, S. Doiyama, J. Azumi, Y. Shimada, Y. Tokuji, H. Yamaguchi, K. Nagata, N. Sakamoto, H. Aso and T. Nakamura, Organogermanium suppresses cell death due to oxidative stress in normal human dermal fibroblasts, Sci. Rep. 9 (2019) Article ID 13637; https://doi.org/10.1038/s41598-01949883-7

34. H. Aso, F. Suzuki, T. Ebina and N. Ishida, Antiviral activity of carboxyethylgermanium sesquioxide (Ge-132) in mice infected with influenza virus, J. Biol. Response Mod. 8 (1989) 180-189.

35. M. Kuwabara, S. Ohba and M. Yukawa, Effect of germanium, poly-trans-[2-carboxyethyl] germasesquioxane on natural killer (NK) activity in dogs, J. Vet. Med. Sci. 64 (2002) 719-721; https:// doi.org/10.1292/jvms.64.719

36. N. Nagahama, M. Okada and Y. Minamishima, Protective effects of Ge-132 (an organic germanium compounds) on murine cytomegalovirus infection, Chemotherapy 35 (1987) 546-550.

37. F. Suzuki, R. R. Brutkiewicz and R. B. Pollard, Importance of T-Cells and macrophages in the antitumor activity of carboxyethylgermanium sesquioxide (Ge-132), Anticancer Res. 5 (1985) 479-483.

38. C. P. Si, X. L. Dang, J. Yu, J. Yang and M. Y. Yi, The enhancement effect of organic germanium (Ge-132) on immune function, Shanghai J. Immunol. 14 (1994) 14-15.

39. Y. Chen and Y. Shi, Inhibitory effect of Ge-132 on the tumor lesion of marek, disease and its mechanism, Chin. J. Vet. Sci. 14 (1994) 18-22.

40. O. P. Kolesnikova, M. N. Tuzova, I. V. Safronova, O. T. Kudayeva and V. A. Kozlov, Study of the effect of derivatives of indolyl-3-acetate and germanium-organic compounds on the model of autoimmune glomerulonephritis induced by chronic graft-versus-host reaction, Immunology 3 (1996) 43-46.

41. A. N. Narovlyanskiy, [Cellular resistance to interferon-in Russian], Nauchnye Doki Vyss Shkoly Biol. Nauki (Moscow) 9 (1991) 5-20.

42. H. Aso, F. Suzuki, T. Yamaguchi, Y. Hayashi, T. Ebina and N. Ishida, Induction of interferon and activation of NK cells and macrophages in mice by oral administration of Ge-132, an organic germanium compound, Microbiol. Immunol. 29 (1985) 65-74; https://doi.org/10.1111/j.1348-0421.1985. tb00803.x

43. T. Munakata, S. Arai, K. Kuwano, M. Furukawa and Y. Tomita, Induction of interferon production by natural killer cells by an organogermanium compounds, Ge 132, J. Interferon Res. 7 (1987) 69-76; https://doi.org/10.1089/jir.1987.7.69

44. K. Ikemoto, M. Kobayashi, T. Fukumoto, M. Morimatsu, R. B. Pollard and F. Suzuki, 2-Carboxyethylgermanium sesquioxide, a synthetic organogermanium compound, as an inducer of contrasuppressor T cells, Experientia 52 (1996) 159-166; https://doi.org/10.1007/BF01923363

45. L. Prónai and S. Arimori, Decreased plasma superoxide scavenging activity in immunological disorders--carboxyethylgermanium sesquioxide (Ge-132) as a promoter of prednisolone, Biotherapy 4 (1992) 1-8; https://doi.org/10.1007/BF02171703

46. L. Prónai and S. Arimori, Protective effect of carboxyethylgermanium sesquioxide (Ge-132) on superoxide generation by 60Co-irradiated leukocytes, Biotherapy 3 (1991) 273-279; https://doi.org/10.1007/ BF02171692

47. Y. Q. Chen, B. Tian, X. M. Li, Y. J. Chen and S. H. Xie, [Effect of carboxyethylgermanium sesquioxide on cultured normal neonatal rat myocardial cells and cells injured by isoproterenol] Yao Xue Xue Bao (Acta Pharm. Sin.) 27 (1992) 481-485.

48. E. Ya. Lukevich, T. K. Gar, L. M. Ignatovich and V. F. Mironov, [Biological Activity of Germanium Compounds - in Russian], Zinatne, Riga 1990.

49. Y. Ishiwata, E. Suzuki, S. Yokochi, T. Otsuka, F. Tasaka, H. Usuda and T. Mitani, Studies on the antiviral activity of propagermanium with immunostimulating action, Arzneimittelforschung $\mathbf{4 4}$ (1994) 357-361.

50. S. H. Tao and P. M. Bolger, Hazard assessment of germanium supplements, Regul. Toxicol. Pharmacol. 25 (1997) 211-219; https://doi.org/10.1006/rtph.1997.1098 
51. R. A. Reddeman, R. Glávits, J. R. Endres, T. S. Murbach, G. Hirka, A. Vértesi, E. Bérez and I. P. Szakonviné, A toxicological evaluation of germanium sesquioxide (organic germanium), J. Toxicol. 2020 (2020) Article ID 6275625; https://doi.org/10.1155/2020/6275625

52. B. J. Kaplan, G. M. Andrus and W. W. Parish, Germane facts about germanium sesquioxide: II. Scientific error and misrepresentation, J. Altern. Complement. Med. 10 (2004) 345-348; https://doi. org/10.1089/107555304323062338

53. Online-directory of medical products Vidal, Description of the Veterinary Medicinal Product MAXIDIN 0.4; https://www.vidal.ru/veterinar/maxidin-0-4-28423; last access date March 10, 2021

54. A. V. Sanin, V. V. Annikov, O. N. Narovlyansky, A. V. Pronin and M. V. Mezentseva, [Effect of Maxidin on the general resistance of dogs], Sci. Mess. LNUVMB (Lviv, Ukraine) 19 (2017) 90-93; https:// doi.org/10.15421/nvlvet7818

55. H. O. Byts, [Prevention of gastroenteritis in calves with using medications of selenium and germanium], Sci. Mess. LNUVMB (Lviv, Ukraine) 12 (2010) 3-6.

56. V. V. Veselovskij, I. I. Danilov, S. D. Mal'tsev, A. V. Pronin, A. N. Narovlyanskiy, A. V. Sanin, A. V. Deeva and A. M. Amchenkova Complex of germanium and 2,6-pyridine dicarboxylic acid 1: method of its preparing, pharmaceutical composition, RU Pat. 2171259, 05 Sep 1997.

57. V. I. Velychko, I. K. Avdosieva, O. M. Shchebentovs'ka, B. I. Kushnir and A. H. Pashchenko, [The perspectives of the application of microelement mixture Hermakap in the sphere of poultry husbandry], Sci. Mess. LNUVMB (Lviv, Ukraine) 17 (2015) 11-16.

58. M. I. Zhyla, I. K. Avdos'eva, A. H. Pashchenko, L. V. Kalynovska and G. M. Mihalus, [Clinical trials of Germacap therapeutic effectiveness on calves], Sci. Mess. LNUVMB (Lviv, Ukraine) 18 (2016) $42-47$.

59. M. Jung, H.-T. Park, J-H. Park, K.-N. Lee, S. W. Shin, M.-K. Shin, K. Y. Sung, Y. K. Jung, B. Kim and H. S. Yoo, Effects of germanium biotite supplement on immune responses of vaccinated mini-pigs to foot-and-mouth disease virus challenge, Immunol. Invest. 44 (2015) 101-112; https://doi.org/10.3109/08 820139.2014.938164

60. M. Jung, M.-K. Shin, S.-B. Cha, S. W. Shin, A. Yoo, W.-J. Lee, H.-T. Park, J.-H. Park, B. Kim, Y.-K. Jung and H. S. Yoo, Supplementation of dietary germanium biotite enhances induction of the immune responses by foot-and-mouth disease vaccine in cattle, BMC Vet Res. 10 (2014) Article ID 179 (10 pages); https://doi.org/10.1186/s12917-014-0179-6

61. M. Jung, B.-G. Jung, S. B. Cha, M.-K. Shin, W.-J. Lee, S. W. Shin, J.-A. Lee, Y.-K. Jung, B.-J. Lee and H. S. Yoo, The effects of germanium biotite supplement as a prophylactic agent against respiratory infection in calves, Pak. Vet. J. 32 (2012) 319-324.

62. N. G. Grushka, S. I. Pavlovych, O. A. Kondratska, N. O. Pilkevcih and R. I. Yanchii, The protective effect of germanium citrate on functional state of immune cells and neutrophil activity under the condition of lipolysaccharide induced inflammation, Fiziol. Zh. 65 (2019) 43-50; https://doi. org/10.15407/fzz65.06.043

63. M. Khrabko, R. Fedoruk and S. Kropivka, [Indicators of the immune and antioxidant systems in the blood of pregnant female rats F1 upon action of different doses of germanium citrate], Bull. Taras Shevchenko Nat. Univ. Kyiv (Kyiv, Ukraine) 22 (2017) 50-53.

64. O. P. Dolaychuk, R. S. Fedoruk, I. I. Kovalchuk and S. Y. Kropyvka, Physiological and biochemical processes in the organisms of rats that were fed with different amounts of germanium citrate, Biol. Tvarin 17 (2015) 50-56; https://doi.org/10.15407/animbiol17.02.050

65. V. A. Liashenko, N. K. Akhmatova, I. V. Ambrosov, S. K. Matelo, E. A. Akhmatov, A. S. Sukhno and V. G. Khomenkov, [Activation of lymphocytes under the influence of an influenza vaccine combined with a low molecular weight germanium organic compound], Zh. Mikrobiol. Epidemiol. Immunobiol. 6 (2012) 64-68.

66. V. A. Liashenko, N. K. Akhmatova, I. V. Ambrosov, S. K. Matelo, S. G. Markushin, E. A. Akhmatov, A. S. Sukhno and V. G. Khomenkov, [Activating effect of a germanium-organic compound on immunocompetent cells during intranasal immunization of mice with a live influenza vaccine], $Z h$. Mikrobiol. Epidemiol. Immunobiol. 3 (2013) 60-68. 
67. O. Yoshinar, Y. Shiojima and K. Igarashi, Hepatoprotective effect of germanium-containing Spirulina in rats with (D)-galactosamine-and lipopolysaccharide-induced hepatitis, Br. J. Nutr. 111 (2014) 135140; https://doi.org/10.1017/S0007114513001943

68. J. M. Cho, J. Chae, S. R. Jeong, M. J. Moon, D. Y. Shin and J. H. Lee, Immune activation of biogermanium in a randomized, double-blind, placebo-controlled clinical trial with 130 human subjects: Therapeutic opportunities from new insights, PLOS ONE 15 (2020) e0240358; https://doi. org/10.1371/journal.pone.0240358

69. J.-S. Lee, J.-I. Park, S.-H. Kim, S.-H. Park, S.-K. Kang, C.-B. Park, T.-U. Sohn, J. Y. Jang, J.-K. Kang and Y.-B. Kim, Oral single- and repeated-dose toxicity studies on Geranti Bio-Ge yeast, organic germanium fortified yeasts, in rats, J. Toxicol. Sci. 29 (2004) 541-553; https://doi.org/10.2131/jts.29.541

70. D. H. Baek. W. J. Jin, U. S. Tsang and K. K. Jong, Germanium-fortified yeast activates macrophage, NK cells and B cells and inhibits tumor progression in mice, Kor. J. Microbiol. Biotechnol. 35 (2007) $118-127$.

71. J. H. Lee, K. W. Kim, M. Y. Yoon, J. Y. Lee, C. J. Kim and S. S. Sim, Anti-inflammatory effect of germanium-concentrated yeast against paw oedema is related to the inhibition of arachidonic acid release and prostaglandin $\mathrm{E}_{2}$ production in RBL 2H3 cells, Auton. Autacoid Pharmacol. 25 (2005) 129_ 134; https://doi.org/10.1111/j.1474-8673.2005.00335.x

72. S. Choi, C. Oh, J. Han, J. Park, J.-H. Choi, N. Y. Min, K.-H. Lee, A. J. Park, Y. J. Kim, S. J. Jang, D.-H. Lee and S. W. Ham, Synthesis and biological evaluation of water-soluble organogermanium, Eur. J. Med. Chem. 45 (2010) 1654-1656; https://doi.org/10.1016/j.ejmech.2009.12.069

73. L. L. Than, G. Y. Zhang and B. G. Wang, Study on vitro anti-respiratory virus infection effect of organogermanium poly-derivatives, Carcinogenesis Teratogenesis Mutagenesis 16 (2004) 349-351.

74. S. Yao, J. Jiang, P. Yang and J.-Y. Cai, Synthesis, characterization and antioxidant activity of a novel organogermanium sesquioxide with resveratrol, Bull. Korean Chem. Soc. 33 (2012) 1121-1122; https:// doi.org/10.5012/bkcs.2012.33.4.1121

75. J. Pi, J. Zeng, J.-J. Luo, P.-H. Yang and J.-Y. Cai, Synthesis and biological evaluation of germanium (IV)-polyphenol complexes as potential anti-cancer agents, Bioorg. Med. Chem. Lett. 23 (2013) 2902 2908; https://doi.org/10.1016/j.bmcl.2013.03.061

76. J. Jiang, S. Yao, H.-H. Cai, P.-H. Yang and J. Cai, Synthesis and synergetic effects of chrysinorganogermanium (IV) complex as potential antioxidant, Bioorg. Med. Chem. Lett. 23 (2013) 5727-5732; https://doi.org/10.1016/j.bmcl.2013.07.073

77. S. P. Li, W.-L. Xie, H.-H. Cai, J.-Y. Cai and P.-H. Yang, Hydroxyl radical scavenging mechanism of human erythrocytes by quercetin-germanium (IV) complex, Eur. J. Pharm. Sci. 47 (2012) 28-34; https:// doi.org/10.1016/j.ejps.2012.04.019

78. C.-W. Oh, M. Li, E.-H. Kim, J.-S. Park, J.-H. Lee and S. W. Ham, Antioxidant and radical scavenging activities of ascorbic acid derivatives conjugated with organogermanium, Bull. Korean Chem. Soc. 31 (2010) 3513-3514; https://doi.org/10.5012/BKCS.2010.31.12.3513

79. D. H. Lim, M. Li, E.-H. Kim and S. W. Ham, Synthesis of novel organogermanium derivative conjugated with vitamin C and study of its antioxidant effects, Bull. Korean Chem. Soc. 31 (2010) 1839-1840; https:// doi.org/10.5012/bkcs.2010.31.7.1839

80. D. H. Lim, M. Li, J.-A. Seo, K.-M. Lim and S. W. Ham, A novel organogermanium protected atopic dermatitis induced by oxazolone, Bioorg. Med. Chem. Lett. 20 (2010) 4032-434; https://doi.org/10.1016/j. bmcl.2010.05.097

81. Z. Amtul, C. Follmer, S. Mahboob, A.-Ur-Rahman, M. Mazhar, K. M. Khan, R. A. Siddiqui, S. Muhammad, S. A. Kazmi and M. I. Choudhary, Germa- $\gamma$-lactones as novel inhibitors of bacterial urease activity, Biochem. Biophys. Res. Commun. 356 (2007) 457-463; https://doi.org/10.1016/j.bbrc.2007.02.158

82. A. M. Badawi and A. A. Hafiz, Synthesis and immunomodulatory activity of some novel amino acid germanates, J. Iran. Chem. Soc. 4 (2007) 107-113; https://doi.org/10.1007/BF03245808 
83. I. V. Nizhenkovskaya, I. I. Seifullina, V. P. Narokha, O. E. Martsinko and E. A. Chebanenko, [Study of antioxidant properties of the complex of germanium with nicotinic acid (MIGU-1) in experimental chronic heart failure], Pharmacol. Drug Toxicol. 2 (2016) 74-79.

84. I. V. Nizhenkovskaya, V. P. Narokha, O. V. Kuznetsova, T. S. Bryzgina, I. I. Seifullina, E. E. Martsinko and E. A. Chebanenko, [Effects of nicotinic acid and complex of germanium with nicotinic acid (MIGU-1) on lipid fatty acid composition of cardiomyocytes and hepatocytes in rats with experimental chronic heart failure], Pharmacol. Drug Toxicol. 1 (2015) 68-75.

85. V. Narokha, [The effect of different doses of the coordination compound germanium with nicotinic acid on the processes of lipid peroxidation and the comparative effect of coordination compounds of germanium with different bioligands on the fatty acid spectrum of cardiomyocyte lipids in chronic doxorubicin intoxication], Ukr. Sci. Med. Youth J. 2 (2016) 86-91.

86. V. Narokha, [The effect of the germanium complex with nicotinic acid on oxidative modification of cardiac and hepatic proteins in the experimental chronic intoxication with doxorubicin in rats], Clin. Pharm. 20 (2016) 35-38.

87. I. Nizhenkovska, V. Narokha and O. Kuznetsova, Effects of nicotinic acid on protein oxidative modifications in experimental chronic heart failure, Farmacia 66 (2018) 959-962; https://doi.org/10.31925/ FARMACIA.2018.6.5

88. V. Narokha, I. Nizhenkovska and O. Kuznetsova, Antioxidant effect of nicotinic acid on experimental doxorubicin-induced chronic heart failure, Curr. Top. Pharmacol. 18 (2014) 105-111.

89. M. Zeman, M. Vecka, F. Perlik, B. Stankova, R. Hromadka, E. Tvrzicka, J. Sirc, J. Hrib and A. Zak, Pleiotropic effects of niacin: Current possibilities for its clinical use, Acta Pharm. 66 (2016) 449-469, https://doi.org/10.1515/acph-2016-0043

90. I. V. Nizhenkovskaya and V. P. Narokha, [Influence of coordination compound of germanium with nicotinic acid on the energy homeostasis of the heart and liver of rats with chronic intoxication with doxorubicin], Recipe 19 (2016) 174-181.

91. V. D. Lukyanchuk, I. J. Seifullina, N. V. Rysukhina, E. E. Martsinko and V. M. Tkachenko, [Screening and comparative efficiency analysis of detoxicative remedies among organic germanium compounds in crush syndrome], Odeskij Med. Z. (Odessa, Ukraine) 1 (2007) 15-19.

92. T. R. Luchishin, N. V. Rysukhina and V. D. Lukyanchuk, [Comparative analysis of the effect of MIGU-5 and thiotriazoline on the content of adenyl nucleotides under conditions of endogenous intoxication], Mozhayev Ukr. J. Extr. Med. 13 (2012) 86-90.

93. V. D. Lukyanchuk, I. I. Seifullina, G. I. Posternak, Ye. A. Shebaldova, N. V. Risukhina and E. E. Martsinko, [Acid-base balance in animals with confined space hypoxia against pharmacological prevention by new germanium coordination compound], Emerg. Med. (Kyiv) 1 (2014) 67-70.

94. I. I. Seifullina, V. D. Lukianchuk and O. D. Nemiatykh, Coordination compound of germanium and nicotinic acid possessing antihypoxic activity, UK Pat. 61375, 17 Nov 2003.

95. V. Lukyanchuk, D. Kravets and D. Litvinenko, Study of pharmacometric indexes of dosing regimen of antihypoxant OKAGERM-4, Georgian Med. News 11 (2017) 144-147.

96. M. V. Matyushkina, V. V. Godovan, L. M. Mudryk and T. L. Gridina, Antimicrobial properties of new coordination compounds of metals with citric acid, Odessa Med. J. 4 (2014) 13-17.

97. I. Seifullina, E. Martsinko, O. Batrakova, N. Borzova, E. Ivanko and L. Varbanets, [Effect of coordinational germanium compounds on enzyme synthesis and activity], Mikrobiol Z. (Kyiv) 64 (2002) 3-11.

98. National Library of Medicine, National Center for Biotechnology Information, 3-(Trihydroxygermyl) propanoic acid (Compound); https://pubchem.ncbi.nlm.nih.gov/compound/3-_Trihydroxygermyl_propanoic-acid; last access date May 16, 2021

99. G. Zhai, W. Zhu, Y. Duan, W. Qu and Z. Yan, Synthesis, characterization and antit https://doi. org/10.1515/mgmc-2012-0026umor activity of the germanium-quercetin complex, Main Group Met. Chem. 35 (2012) 103-109; 